\title{
Variations of glacial lakes and glaciers in the Boshula mountain range, southeast Tibet, from the 1970 s to 2009
}

\author{
Weicai WANG, ${ }^{1,3}$ Tandong YAO, ${ }^{1,2}$ Xiaoxin YANG $^{1}$ \\ ${ }^{1}$ Key Laboratory of Tibetan Environment Changes and Land Surface Processes, Institute of Tibetan Plateau Research, \\ Chinese Academy of Sciences, 18 Shuangqing Road, Beijing 100085, China \\ E-mail: tdyao@itpcas.ac.cn \\ ${ }^{2}$ State Key Laboratory of Cryospheric Sciences, Cold and Arid Regions Environmental and Engineering Research Institute, \\ Chinese Academy of Sciences, 320 Donggang West Road, Lanzhou 730000, China \\ ${ }^{3}$ Graduate University of the Chinese Academy of Sciences, Beijing 100049, China
}

\begin{abstract}
Catastrophic floods originating from glacial lake outbursts have recently become one of the primary natural hazards in the southeastern Tibetan Plateau. Here we report observations of glacial lake expansions and glacier recessions in the Boshula mountain range, southeast Tibet, derived from multitemporal remote-sensing images and digital elevation models during the period from the 1970s to 2009. The area of glacial lakes has expanded from $9.24 \pm 0.1 \mathrm{~km}^{2}$ in the $1970 \mathrm{~s}$ to $10.96 \pm 0.1 \mathrm{~km}^{2}$ in 2009. Specifically, the area of moraine-dammed lakes has increased by $26.8 \%$. From the 1970 s to 2009 , the glacierized area in the Boshula mountain range shrank by $12.7 \%\left(21.2 \mathrm{~km}^{2}\right)$. Increasing mean summer air temperature was the main cause for the glacier recession and lake expansion from the 1970s to 2001, while the combination of increased summer temperature and decreased summer precipitation led to accelerated glacier recession after 2001. Climate warming and ongoing deglaciation play important roles in the expansion of moraine-dammed lakes, calling for intensified monitoring to properly address the hazard potential in the study area.
\end{abstract}

\section{INTRODUCTION}

In recent decades, glaciers on the Tibetan Plateau have retreated rapidly due to climate warming, not only affecting water resources and hydrological processes in the region (Yao and others, 2004, 2007), but also causing the expansion of glacial lakes (Yao and others, 2010) and the potential for glacial lake outburst floods (GLOFs) (Richardson and Reynolds, 2000; Nayar, 2009). To the people living downstream, the GLOFs loom large because of their devastating effect on infrastructure and social resources. The Zhangzhangbo GLOF in 1981 (Xu, 1988; Bajracharya and others, 2007b), the Dig Tsho GLOF in 1985 (Mool and others, 2001b; Bajracharya and others, 2007b) and the Luggye Tso GLOF in 1994 (Mool and others, 2001a; Bajracharya and others, 2007b) are examples of the destructive consequences of GLOFs. However, owing to the relatively remote location of glacial lakes, it was not until recently that researchers began to assess the hazards using scientific methods (e.g. Bajracharya and others, 2007a; Bolch and others, 2008; Fujita and others, 2008, 2009; Wang and others, 2008) and to address the formation (Quincey and others, 2007; Frey and others, 2010; Sakai and Fujita, 2010) and variation (Chen and others, 2007; Komori, 2008) of glacial lakes.

In the southeastern Tibetan Plateau, where the warm and humid moisture from the Indian Ocean significantly influences the local climate, there are a large number of marine-type glaciers (Yao and others, 2008) the retreat of which has given rise to many glacial lakes in front of glacier termini (Yao, 2010). In situ mass-balance measurements indicate that these glaciers melted much faster than the continental or subcontinental glaciers (Yang and others, 2008, 2010), which, in combination with abundant precipitation during the summer monsoon, makes southeast Tibet one of the most GLOF-affected regions of Asia (Ding and
Liu, 1992; Wang and Liu, 2007; Cheng and others, 2008; Liu and others, 2008). For example, China's authoritative websites reported two severe GLOFs in Chamdo and Lhoka, respectively, in Tibet in July 2009. There is therefore an urgent need to monitor the variations of glaciers and glacial lakes in southeast Tibet, so as to assess potential GLOF hazards in the region.

Remote sensing makes it possible to investigate simultaneously a large number of glaciers and glacial lakes in inaccessible mountainous areas (Huggel and others, 2002; Kääb and others, 2005; Quincey and others, 2005; Bolch and others, 2008). However, high-quality remote-sensing images are difficult to obtain for southeast Tibet, as both cloud cover during the monsoon season (mid-May to midSeptember; Yang and others, 2009) and snow cover during winter (November to March; Yang and others, 2009) hinder precise image interpretation. Therefore, in this study we chose only the satellite images acquired during SeptemberNovember in the Boshula mountain range (Xin and others, 2009) and used 1:50 000 topographic maps for the 1970s, high-quality Landsat images for 1988 and 2001, and Advanced Land Observing Satellite (ALOS) Advanced Visible and Near Infrared Radiometer type 2 (AVNIR-2) satellite data for 2009 (Table 1). By combining meteorological data from stations near our study area, we also address the variations of glaciers and glacial lakes in response to possible climate variation.

\section{STUDY AREA}

The Boshula mountain range $\left(29.5-30.0^{\circ} \mathrm{N}, 96.25-96.75^{\circ} \mathrm{E}\right)$ is located at the boundary of Bomi county and Paksho county in the southeastern Tibetan Plateau (Fig. 1). The elevation ranges from 3100 to $6200 \mathrm{~m}$ and the topography is characterized by huge relief differences and steep slopes, 
Table 1. Data used in this study and corresponding applications

\begin{tabular}{|c|c|c|c|}
\hline Source/sensor & Date & Resolution/scale & Application \\
\hline Topographic maps & 1970s* & $1: 50000$ & Glacier mapping, lake identification \\
\hline Landsat TM & 27 Oct 1988 & $30 \mathrm{~m}$ & Glacier mapping, lake identification \\
\hline Landsat ETM+ & 23 Oct 2001 & $30 \mathrm{~m}$ & Glacier mapping, lake identification \\
\hline Landsat TM & 8 Sep 2005 & $30 \mathrm{~m}$ & Supplementary image \\
\hline ALOS AVNIR-2 & 14 Oct 2009 & $10 \mathrm{~m}$ & Glacier mapping, lake identification \\
\hline
\end{tabular}

*The study area lies within six sheets of topographic maps. These maps are based on aerial photographs acquired in 1968,1975 and 1980 . For simplicity, we use '1970s' to indicate this period.

with National Highway No. 318 (Sichuan-Tibet Highway) winding through this area. Within the domain of the Indian monsoon, the Boshula mountain range is significantly influenced by warm and humid moisture in summer.

\section{DATA AND METHODS}

Data

Topographic maps of 1:50000 scale constructed from 1970 s aerial photography and corresponding digital elevation models (DEMs) with 20 m equidistant contour lines and $25 \mathrm{~m}$ cell size were used as the benchmark data to detect the variations of glaciers and glacial lakes since that time. Topographic maps were scanned into digitized products at a resolution of 300 dots per inch (dpi) followed by geometric calibration using ERDAS 9.1 software. Remote-sensing images presented in this paper were all acquired from different sensors during September and October with low cloud cover and snow cover, so they are conducive to analyzing glacier and glacial-lake variation in this area. In data processing, Landsat images were co-registered with the $1: 50000$ scale topographic maps. The ALOS AVNIR-2 data were then orthorectified with DEM and topographic maps using the PCl Geomatica OrthoEngine module. All satellite images were converted into the Universal Transverse Mercator projection and Krasovsky 1940 spheroid, which is the same projected coordinate system as the topographic maps. Image co-registration was based on ground-control points, which were collected from the topographic maps and identified on the satellite images. The root-mean-square errors for Landsat Thematic Mapper (TM) (1988), Enhanced TM Plus (ETM+) (2001) and ALOS (2009) were 21.62, 19.36 and $5.06 \mathrm{~m}$, respectively.

\section{Identification of glaciers and glacial lakes}

Glacial lakes and glaciers were delineated manually from digitized topographic maps and/or false-color composite (FCC) satellite images pixel by pixel in ArcGIS 9.2. Though relatively labor-intensive and time-consuming, manual delineation presents more accurate surface-feature mapping than band algebraic approaches such as the normalizeddifference snow index or the normalized-difference water index (Paul and others, 2002). Owing to the relatively low resolution of Landsat imagery, we only analyzed the changes of glacial lakes when they were larger than $0.02 \mathrm{~km}^{2}$ (Chen and others, 2007). After digitizing the individual images periodically, vector layers of glacial lakes and glaciers were obtained for four periods: the 1970s, 1988, 2001 and 2009.
For vector layers of glacial lakes, the type, area, altitude and perimeter of lakes were presented by way of eye-witness interpretation and geographic calculation as attribute data. For vector layers of glaciers, glacier catchments were segmented based on the Global Land Ice Measurements from Space (GLIMS) algorithm (http://www.glims.org/ MapsAndDocs/assets/GLIMS_Analysis_Tutorial_a4.pdf) to identify the mother glaciers in the upper reaches that feed corresponding glacial lakes. Detailed procedures include: (1) filling DEM sinks; (2) creating a flow direction grid; (3) finding glacier toes; (4) producing watersheds; and (5) separating ice polygons into different glacier individuals.

\section{Area uncertainties}

Since we use multitemporal images with different spatial resolutions to study the changes of glaciers and glacial lakes, our results may contain two types of uncertainty which are evaluated quantitatively below.

\section{Error in co-registration}

According to Hall and others (2003) and Ye and others (2006), the uncertainty in co-registration of multitemporal images can be quantified as

$$
\begin{gathered}
U_{\mathrm{L}}=\sqrt{\sum \lambda^{2}}+\sqrt{\sum \sigma^{2},} \\
U_{\mathrm{A}}=\frac{\left(2 U_{\mathrm{L}}\right)}{\sqrt{\sum \lambda^{2}}} \times \sum \lambda^{2}+\sum \sigma^{2},
\end{gathered}
$$

where $U_{\mathrm{L}}$ is the linear uncertainty $(\mathrm{m}), U_{\mathrm{A}}$ is the area uncertainty $\left(\mathrm{m}^{2}\right), \lambda$ is the original pixel resolution of each individual image $(\mathrm{m})$ and $\sigma$ is the co-registration error of each individual image to the topographic maps $(\mathrm{m})$. Accordingly, the maximum error in co-registration $\left(U_{A}\right)$ for changes in glaciers and glacial lakes from the 1970s to 2009 was calculated as $\pm 0.008 \mathrm{~km}^{2}$.

\section{Error introduced by glacier/glacial lake outline delineation}

According to the spatial resolution and quality of each image, we estimate the average accuracy of the glacier/ glacial-lake outlines derived from manual digitizing to be $1.0,1.5,1.0$ and 1.0 pixels, respectively, for the 1970s (topographic maps), 1988 (Landsat TM), 2001 (ETM+) and 2009 (ALOS) datasets. Note that owing to the remaining snow cover during remote sensing in 1988, images for that period have a relatively large estimation uncertainty. The uncertainties of glacier/glacial-lake area were thus determined as the length of shorelines multiplied by the estimated 


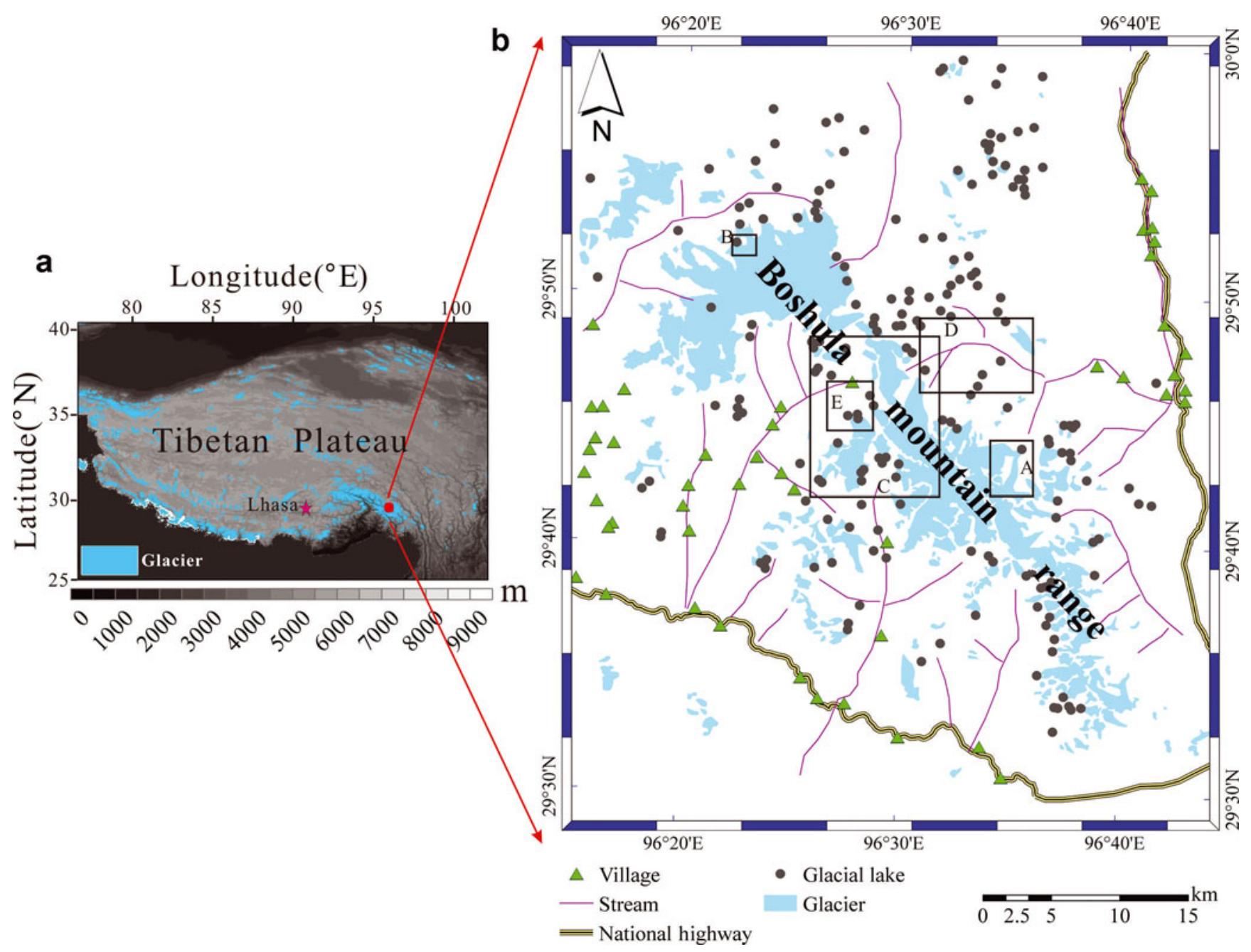

Fig. 1. (a) Location of the Boshula mountain range on the Tibetan Plateau. (b) Glaciers, glacial lakes and villages in the study area. See Figures $5 \mathrm{a}$ and $\mathrm{b}, 3$ and $7 \mathrm{~b}$ and $\mathrm{d}$ for detail in frames $\mathrm{A}, \mathrm{B}, \mathrm{C}, \mathrm{D}, \mathrm{E}$, respectively.

error of outline delineation (Racoviteanu and others, 2008; Fujita and others, 2009; Wang and others, 2009). The total areal uncertainty was estimated as the sum of the aforementioned two errors.

\section{RESULTS}

\section{Glacial lake variation}

Glacial lakes can be categorized by their causes into three types: moraine-dammed, trough-valley and landslidedammed lakes. Table 2 shows the number and area of glacial lakes of different types during four periods. From the 1970s to 2009 , we calculated an $18.6 \%$ expansion in the area of glacial lakes, with the expansion rate reaching $0.55 \% \mathrm{a}^{-1}$ (assuming the beginning year is 1975). This expansion rate is similar to those of the Ranwu lake region $\left(0.47 \% \mathrm{a}^{-1}\right.$; Xin and others, 2009) and the Pumqu river basin $\left(0.52 \% \mathrm{a}^{-1}\right.$; Che and others, 2004), but smaller than those of the Poiqu river basin $\left(3.33 \% \mathrm{a}^{-1}\right.$; Chen and others, 2007) and the Luozha area $\left(1.14 \% \mathrm{a}^{-1} ; \mathrm{Li}, 2010\right)$. From the 1970 s to 2001 , glacial lakes expanded by $0.05 \mathrm{~km}^{2} \mathrm{a}^{-1}$, increasing to $0.07 \mathrm{~km}^{2} \mathrm{a}^{-1}$ thereafter until 2009, indicating the acceleration of glacial lake expansion in the last decade. Moraine-dammed lakes were

Table 2. Variation of number and area $\left(\mathrm{km}^{2}\right)$ of different types of glacial lake

\begin{tabular}{|c|c|c|c|c|c|c|c|c|}
\hline \multirow[t]{2}{*}{ Type } & \multicolumn{2}{|c|}{$1970 \mathrm{~s}$} & \multicolumn{2}{|c|}{1988} & \multicolumn{2}{|c|}{2001} & \multicolumn{2}{|c|}{2009} \\
\hline & Number & Area & Number & Area & Number & Area & Number & Area \\
\hline Moraine-dammed lake & 49 & 5.79 & 53 & 6.48 & 66 & 6.94 & 78 & 7.34 \\
\hline Trough-valley lake & 47 & 3.45 & 45 & 3.37 & 41 & 2.71 & 44 & 2.84 \\
\hline Landslide-dammed lake & 0 & 0 & 0 & 0 & 1 & 0.78 & 1 & 0.78 \\
\hline Total & 96 & $9.24 \pm 0.1$ & 98 & $9.85 \pm 0.3$ & 108 & $10.43 \pm 0.2$ & 123 & $10.96 \pm 0.1$ \\
\hline
\end{tabular}



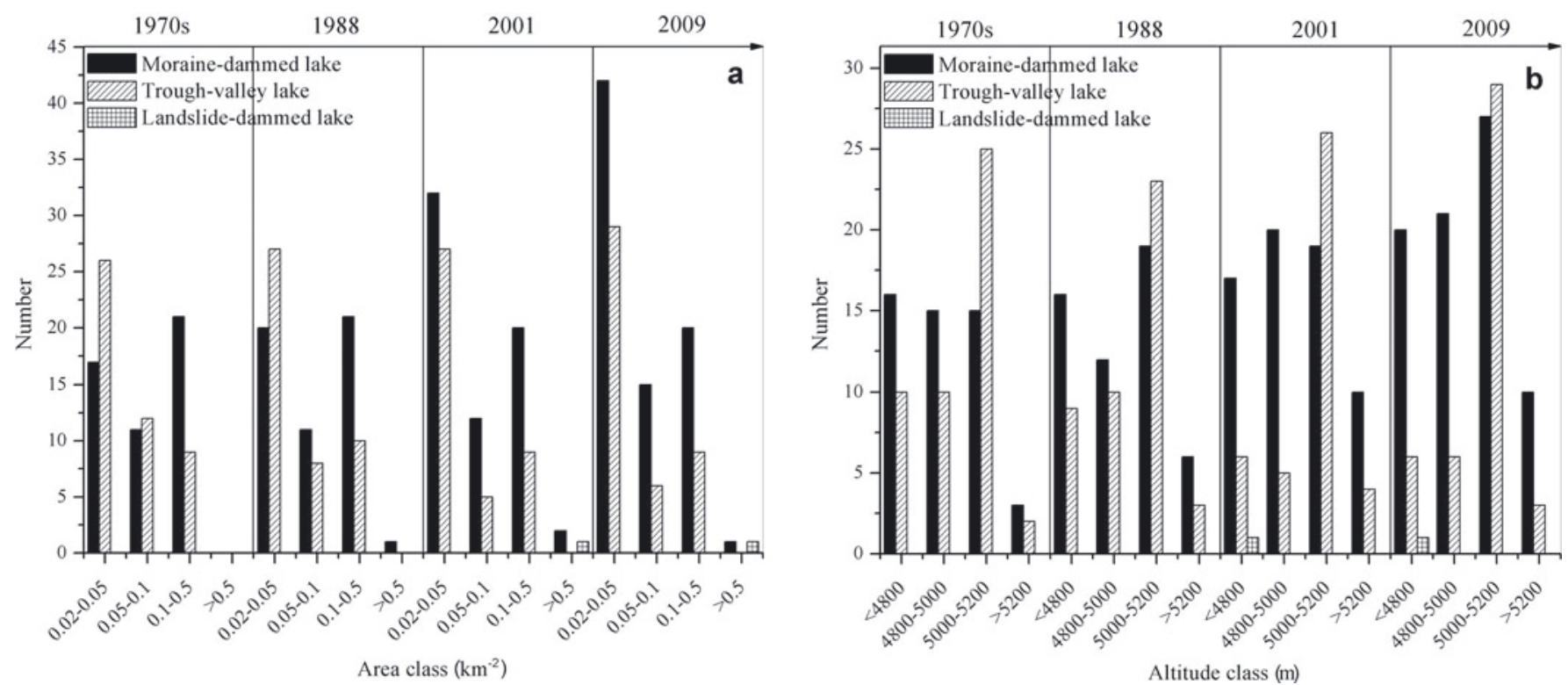

Fig. 2. Numbers of different types of glacial lake from the 1970 s to 2009 , by (a) area class and (b) altitudinal range.

predominant in this area both in number and area, also contributing mainly to the expansion of glacial lakes. From the 1970 s to 2009 , moraine-dammed lakes expanded by $1.55 \mathrm{~km}^{2}$, a $26.8 \%$ increase, while trough-valley lakes showed a slight decrease in area (Table 2).

Glacial lakes can also be categorized by area into four classes: small (lake area $\left.0.02-0.05 \mathrm{~km}^{2}\right)$, medium $(0.05-$ $\left.0.10 \mathrm{~km}^{2}\right)$, large $\left.0.10-0.50 \mathrm{~km}^{2}\right)$ and giant $\left(\geq 0.50 \mathrm{~km}^{2}\right)$. Nearly half of the glacial lakes in this area are small and the number of small glacial lakes has been increasing since the 1970s (Fig. 2a). The emergence of new small lakes in recent decades is clearly observable in Figure 3, and numerous lakes are seen in the 2009 ALOS image that were not present when the topographic maps were produced in the 1970s. In comparison to the increasing number of small moraine-dammed lakes, no apparent changes occurred in trough-valley lakes (Fig. 2a). This suggests that the new emerging lakes in southeast Tibet were primarily morainedammed. In addition, glacial lakes are located at different elevations, with the distribution of trough-valley lakes being more concentrated within the range 5000-5200 ma.s.l. Moraine-dammed lakes are more widespread and are evenly distributed within three major altitudinal ranges: $<4800 \mathrm{~m}$, $4800-5000 \mathrm{~m}$ and $5000-5200 \mathrm{~m}$ (Fig. 2b). The number of moraine-dammed lakes in each altitudinal range increased from the 1970s to 2009, while the number of trough-valley lakes remained steady or even slightly decreased over these decades (Fig. 2b).

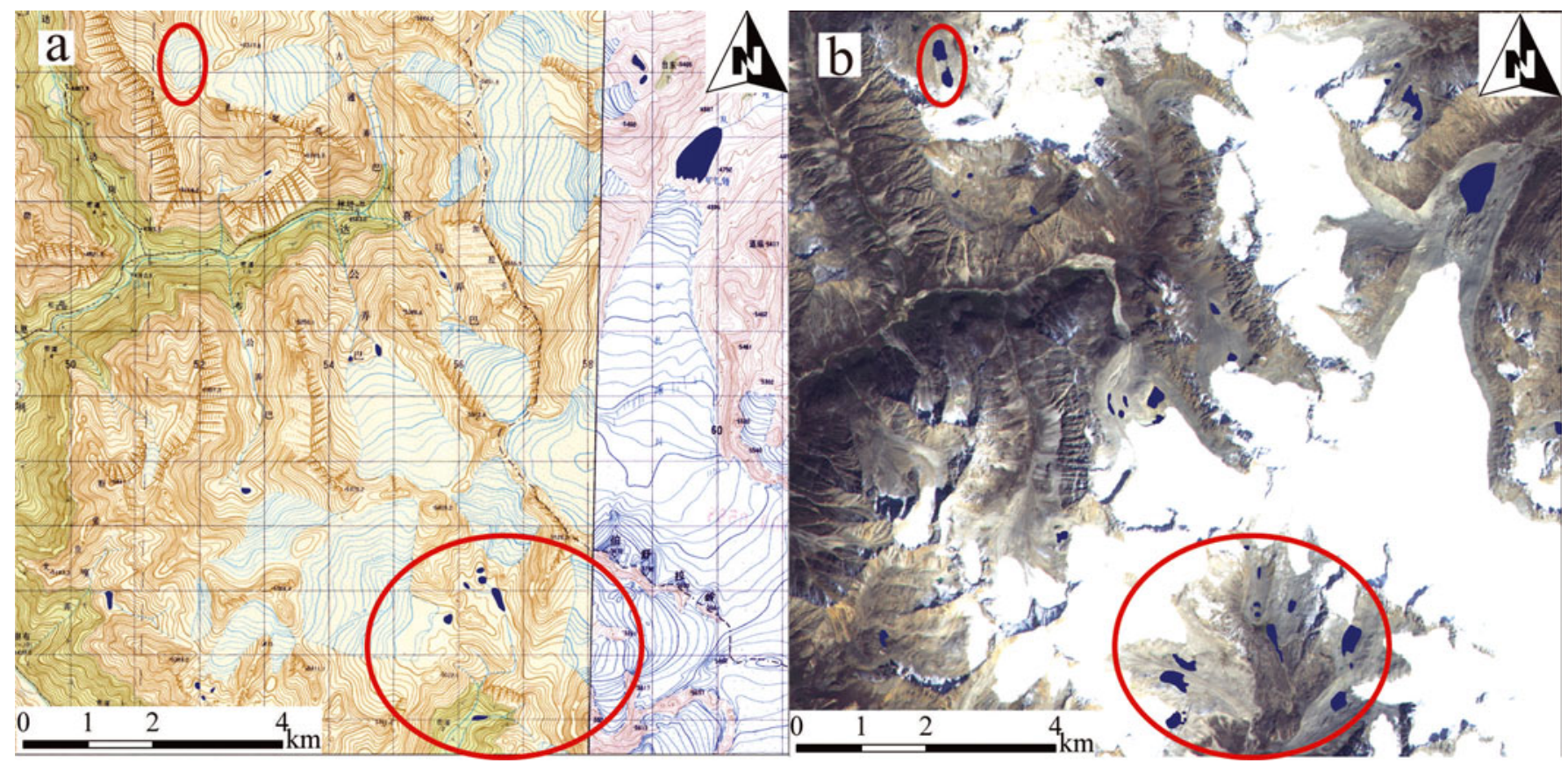

Fig. 3. New emergences of glacial lakes in the study area. (a) Topographic map of 1975; (b) ALOS image of 2009. 


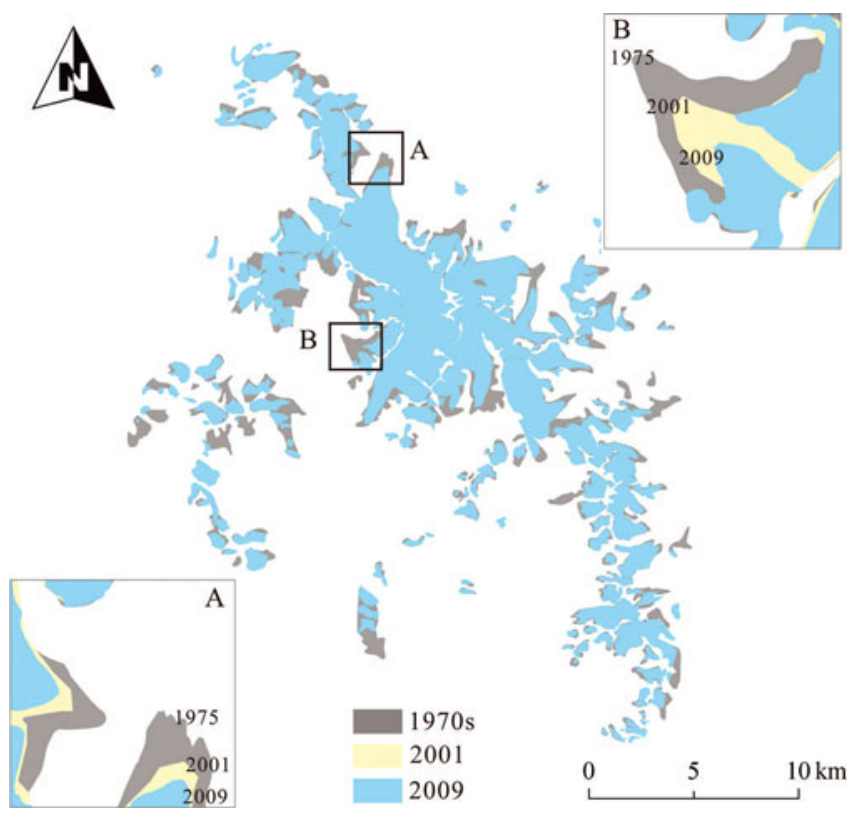

Fig. 4. Glacier area changes in the Boshula mountain region between the 1970s and 2009.

\section{Glacier variation}

Careful inspection of the 1970s images revealed seasonal snow cover in the northern part of the Boshula mountain range, so we eliminated this part from the study area when analyzing glacier variation. Glacier variation in the study area is dominated by significant recession (Fig. 4), which coincides with glacier variations since the early 20th century in the Kangri Karpo mountains (Liu and others, 2005), approximately $100 \mathrm{~km}$ south of the Boshula mountain range. Calculations from topographic maps and remote-sensing images show the glacierized area in the $1970 \mathrm{~s}$ $\left(167.5 \pm 0.5 \mathrm{~km}^{2}\right)$ decreasing consecutively to $162.8 \pm 3.2$
Table 3. Variation of glaciers in the Boshula mountain range from the 1970 s to 2009

\begin{tabular}{lcccc}
\hline Year & $\begin{array}{c}\text { Area } \\
\mathrm{km}^{2}\end{array}$ & \multicolumn{2}{c}{ Area change } & $\begin{array}{c}\text { Change rate } \\
\mathrm{km}^{2}\end{array}$ \\
& & & $\% \mathrm{a}^{-1}$ \\
& & & & \\
\hline $1970 \mathrm{~s}$ & $167.5 \pm 0.5$ & & -2.8 & -0.22 \\
1988 & $162.8 \pm 3.2$ & -4.7 & -4.8 & -0.37 \\
2001 & $155.0 \pm 2.1$ & -7.8 & -5.6 & -0.70 \\
2009 & $146.3 \pm 1.0$ & -8.7 & -12.7 & -0.37 \\
Total & & -21.2 & & \\
\hline
\end{tabular}

and $155.0 \pm 2.1 \mathrm{~km}^{2}$ in 1988 and 2001 , respectively, before reaching $146.3 \pm 1.0 \mathrm{~km}^{2}$ in 2009 (Table 3). Thus, from the 1970 s to 2009, the glacierized area in the Boshula mountain range decreased by $21.2 \mathrm{~km}^{2}$ (or $12.7 \%$ of the total glacierized area), retreating at a rate of $0.37 \% \mathrm{a}^{-1}$ (Fig. 4; Table 3).

Different temporal intervals witness different retreat rates: $0.22 \% \mathrm{a}^{-1}$ from the 1970 s to 1988 , increasing to $0.37 \% \mathrm{a}^{-1}$ from 1988 to 2001 and further increasing to $0.70 \% \mathrm{a}^{-1}$ from 2001 to 2009. This trend is consistent with the study of Xin and others (2009) in the Ranwu lake region, southeast Tibet, which also found an accelerated glacier retreat. The retreat of glaciers corresponds closely to the expansion of glacial lakes, especially those at the glacier terminus. As shown in Figure 5, there are two mother glaciers in the center of our study area that underwent rapid melting and shrinkage from the 1970s to 2009, leading to significant expansion of glacial lakes by approximately $180 \%$ and $1400 \%$ respectively at the glacier terminus. Moreover, the disappearance of small glaciers and the fragmentation of large glaciers observed in other mountainous glacierized areas (Paul and others, 2004; Niederer and others, 2008; Bolch and others, 2010; Narama and others, 2010) is also common in our study area (e.g. two cases of glaciers splitting into separate glaciers are seen in Fig. 5).

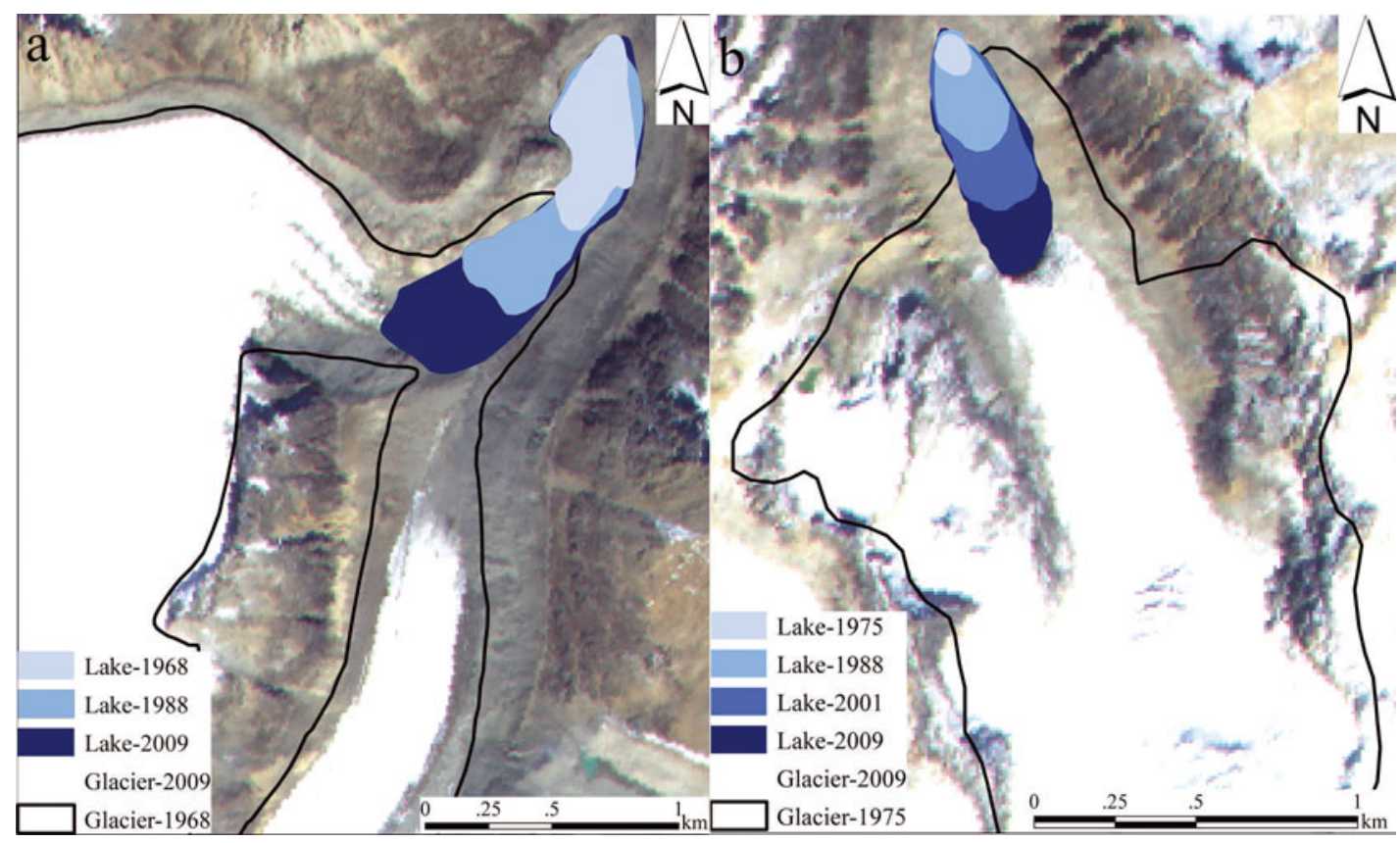

Fig. 5. Two examples $(\mathrm{a}, \mathrm{b})$ of rapid glacier retreat and glacial lake expansion in the study area. The false-color composite ALOS AVNIR-2 image is used as the background. 


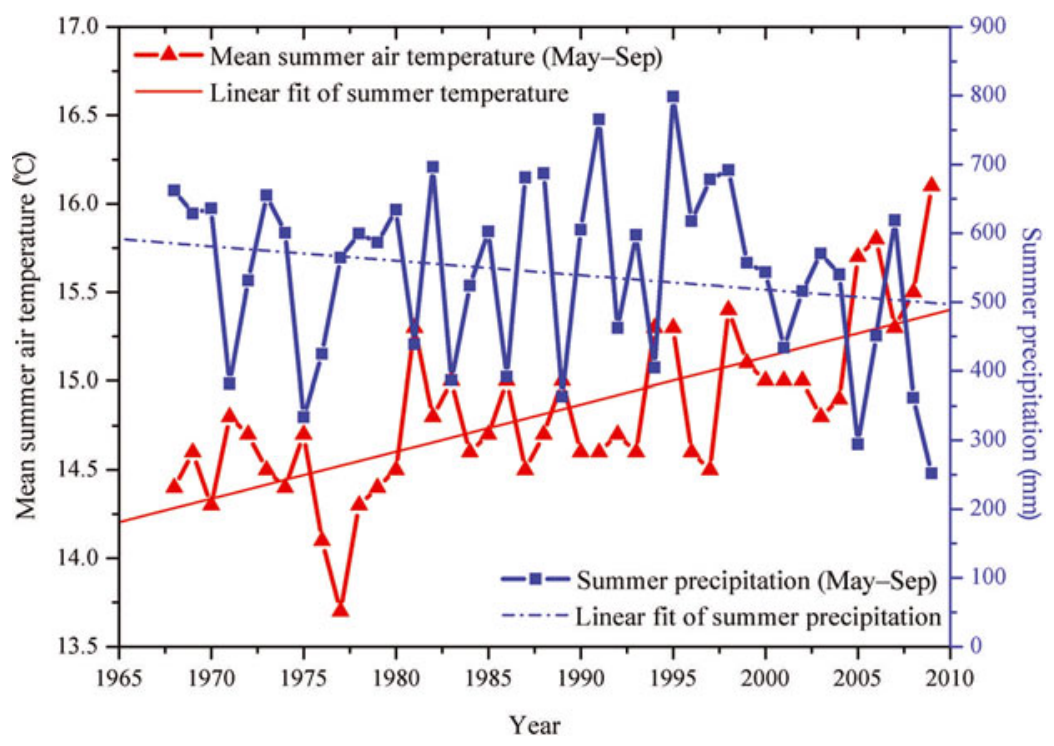

Fig. 6. Variations of summer (May-September) temperature and precipitation from 1968 to 2009 recorded at Bomi meteorological station.

\section{DISCUSSION AND CONCLUSIONS}

\section{The role of temperature and precipitation in the variation of glaciers and glacial lakes}

From the 1970s to 2009, the area of glacial lakes in our study area has increased by $18.6 \%$, while the glaciers have shrunk by $12.7 \%$. Temperature and precipitation are considered as two major climatic factors controlling the changes of glaciers and glacial lakes. As the glaciers in this region are summeraccumulation type and glacier mass balance depends on temperature and precipitation during the summer, we analyzed the fluctuations of temperature and precipitation during May-September. Owing to the lack of meteorological stations in the study area, meteorological data from Bomi station $\left(29.52^{\circ} \mathrm{N}, 95.46^{\circ} \mathrm{E}, 2730 \mathrm{~m}\right.$ a.s.l.; the nearest station, $70 \mathrm{~km}$ west of our study area) were used (Fig. 6). Also dominated by the Indian monsoon, data from the Bomi station can approximate the trend of climate change in the study area. The mean summer air temperature at Bomi station increased significantly $(P<0.0001, n=42)$ during the period $1968-2009$, at a rate of $0.27 \pm 0.04{ }^{\circ} \mathrm{C}(10 \mathrm{a})^{-1}(R=0.69)$. In the most recent decade (1999-2009), the rate of mean summer air-temperature increase of $0.95 \pm 0.29^{\circ} \mathrm{C}(10 \mathrm{a})^{-1}$ $(R=0.74, P<0.01, n=11)$ was nearly 3.5 times higher than during the full period of meteorological data collection.

Although the summer precipitation trend during the period 1968-2009 was not statistically significant at the $5 \%$ level, it demonstrates a sharp diversion in 1998, with the former period (1968-1998) witnessing a slight increase and the latter period (1998-2009) an obvious decrease. Thus, glacier shrinkage and concomitant expansions of glacial lakes in the former period may be attributed to the severe summer air-temperature rise, which counter-balanced and overcame the effect of the slight increase in precipitation. In comparison, intensified warming in the last decade, together with decreasing precipitation, resulted in accelerated glacier retreat in this period.

\section{Impact of glacier shrinkage on glacial lake expansion}

As mentioned above, the moraine-dammed lakes expanded significantly from the 1970 s to 2009, whereas the trough-valley lakes slightly decreased. This contrast in types of glacial lake within the same climate zone may be attributed to the difference in lake water supply. Compared with the trough-valley lakes mainly supplied by precipitation, the moraine-dammed lakes are fed jointly by precipitation and glacial meltwater. If we consider that the outflows of lake water from these two types of glacial lake are generally similar, with mother glacier melting the moraine-dammed lakes will receive more water supply than the trough-valley lakes, resulting in a general expansion of moraine-dammed lakes. For instance, of the 78 moraine-dammed lakes under study, whereas 16 lakes shrank between the 1970s and 2009, 62 other glacial lakes, including 27 new emergences, expanded at a rate of $35 \mathrm{~m}^{2} \mathrm{a}^{-1}$ to $>20000 \mathrm{~m}^{2} \mathrm{a}^{-1}$. In addition, glacier shrinkage will have another impact on moraine-dammed lakes: with the retreat of glacier ice, they may expand to flat areas left by retreating glaciers. This also explains the difference between the variations of morainedammed lakes and trough-valley lakes and shows the impact of glacier shrinkage on glacial lake expansion.

\section{Potential threats of GLOF}

Settlements in the Boshula mountain range are generally located on the terrace in the upper reaches of rivers with glacial meltwater as the major water supply. Though river runoff will increase for a short time with intensified glacier shrinkage, the water supply to support daily livelihoods is no longer sustainable, which has dramatic consequences for long-term well-being in the region. In addition, the more important effect of glacier retreat is the increased frequency of GLOFs or other glacial hazards. According to local historical documents at Chamdo, a devastating GLOF occurred on 12 June 1991, destroying the dams of a local hydrological power station, washing away 11 houses and 144 livestock and destroying extensive sections of the Sichuan-Tibet Highway. This GLOF also led to a severe landslide, forming a landslide-dammed lake measuring $0.78 \mathrm{~km}^{2}$ from the remote-sensing images for 2001 (Fig. $7 \mathrm{a}$ and b). The glacial lake shown in Figure $7 \mathrm{c}$ and $\mathrm{d}$ also caused GLOFs during 2005-09, carrying large glacial moraines downstream, with the deposit clearly identifiable 

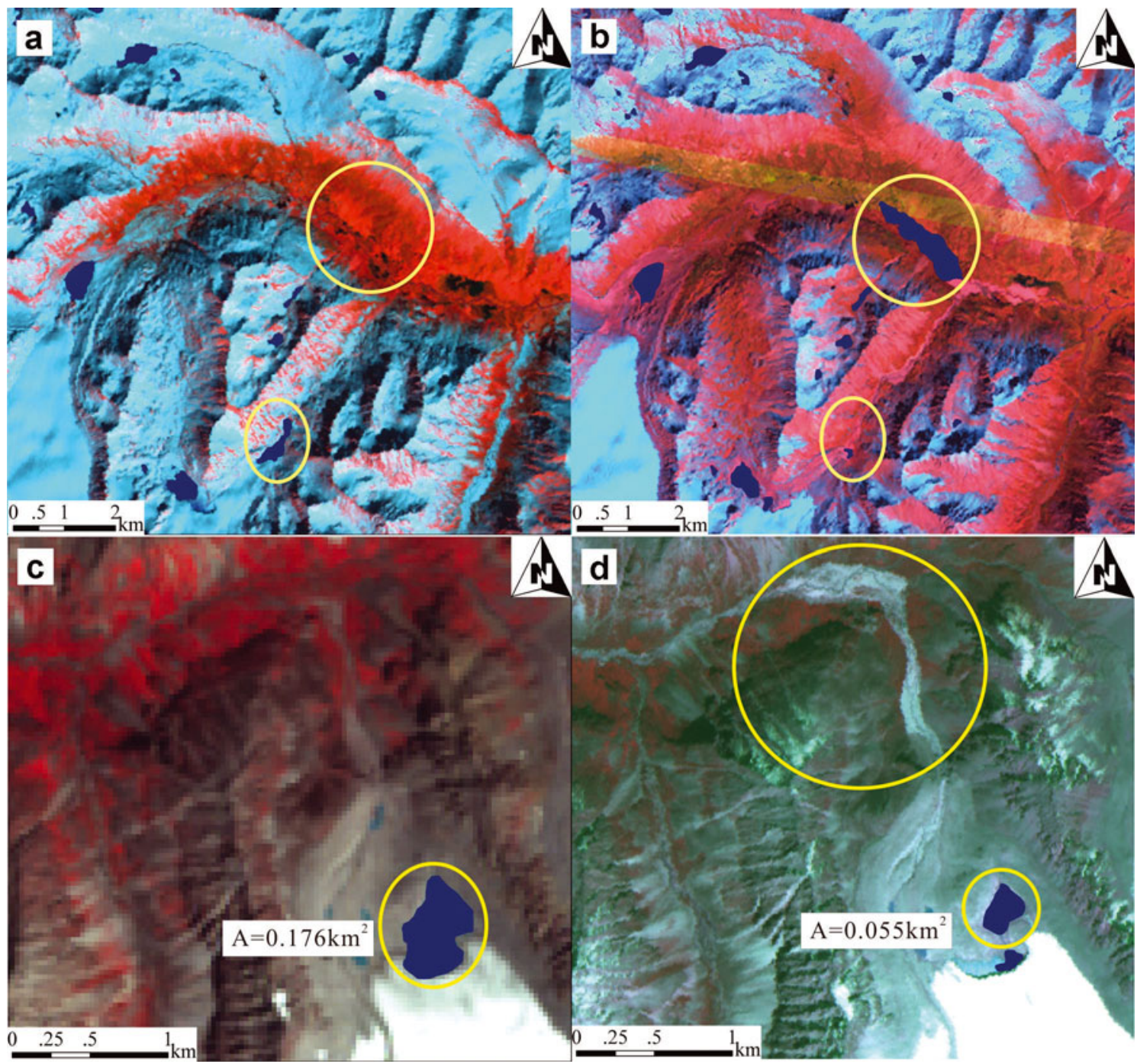

Fig. 7. Two outburst floods revealed by satellite images. (a, b) A landslide-dammed lake was formed after outburst of a glacial lake: (a) Landsat TM image of 1988; (b) Landsat ETM+ image of 2001. (c, d) The deposited sediment bed can be observed as a white trace on the satellite image: (c) Landsat TM image of 2005; (d) ALOS image of 2009.

from remote-sensing images. There is therefore an urgent need to intensify monitoring of glacial lakes and glaciers in the region and to set up early-warning systems in addition to assessing the risks posed by glacial lakes (Shrestha, 2008).

This study also revealed a potentially dangerous lake, Longlikum Co $\left(29^{\circ} 43^{\prime} 55^{\prime \prime} \mathrm{N}, 96^{\circ} 35^{\prime} 23^{\prime \prime} \mathrm{E} ; 4800 \mathrm{~m}\right.$ a.s.I.), which underwent continuous expansion from 0.17 to $0.48 \mathrm{~km}^{2}$ during 1968-2009, corresponding to the mother glacier decreasing from 11.9 to $10.9 \mathrm{~km}^{2}$ (Fig. 5a). The terminus of the mother glacier with a precipitous glacial tongue is connected with the glacial moraine-dammed lake. Given the fact that Longlikum Co is only $4 \mathrm{~km}$ away from the outburst lake shown in Figure $7 \mathrm{a}$, it poses a potential threat to the people and economy of the region. For these extremely dangerous lakes, appropriate engineering countermeasures should be adopted to lower the lake level as soon as possible (Wang, 2008).

\section{ACKNOWLEDGEMENTS}

We thank two anonymous reviewers and the scientific editor, D.R. MacAyeal, for constructive comments on the manuscript. We also thank D.R. Joswiak for kindly polishing the English. This work was supported by the Chinese Academy of Sciences (CAS)/State Administration of Foreign Experts Affairs (SAFEA) International Partnership Program for Creative Research Teams, the External Cooperation Program of the CAS (GJHZ0960), the Knowledge Innovation Program of the CAS(KZCX2-YW-145), the National Natural Science Foundation of China (40810019001) and the Program of Tibet Science and Technology Agency. 1:50000 scale topographic maps and DEMs were supplied by the National Geomatics Center of China (NGCC). Meteorological data from Bomi station were kindly supplied by the China Meteorological Data Sharing Service System.

\section{REFERENCES}

Bajracharya, B., A.B. Shrestha and L. Rajbhandari. 2007a. Glacial lake outburst floods in the Sagarmatha region: hazard assessment using GIS and hydrodynamic modeling. Mt. Res. Dev., 27(4), 336-344.

Bajracharya, S.R., P.K. Mool and B. Shrestha. 2007b. Impact of climate change on Himalayan glaciers and glacial lakes: case studies on GLOF and associated hazards in Nepal and Bhutan. Kathmandu, International Centre for Integrated Mountain 
Development and United Nations Environment Programme Regional Office, Asia and the Pacific. (ICIMOD Publication 169.)

Bolch, T., M.F. Buchroithner, J. Peters, M. Baessler and S. Bajracharya. 2008. Identification of glacier motion and potentially dangerous glacial lakes in the Mt. Everest region/ Nepal using spaceborne imagery. Natur. Hazards Earth Syst. Sci. (NHESS), 8(6), 1329-1340.

Bolch, T., B. Menounos and R. Wheate. 2010. Landsat-based inventory of glaciers in western Canada, 1985-2005. Remote Sens. Environ., 114(1), 127-137.

Che, T., R. Jin, X. Li and L.-Z. Wu. 2004. Glacial lakes variation and the potentially dangerous glacial lakes in the Pumqu Basin of Tibet during the last two decades. J. Glaciol. Geocryol., 26(4), 397-402. [In Chinese with English summary.]

Chen, X.Q., C. Peng, Y. Li, Y. Zhong and Y.Q. Qi. 2007. Changes in glacial lakes and glaciers of post-1986 in the Poiqu River basin, Nyalam, Xizang (Tibet). Geomorphology, 88(3-4), 298-311.

Cheng, Z.L., P.Y. Zhu, C. Dang and J.J. Liu. 2008. Hazards of debris flow due to glacier-lake outburst in southeastern Tibet. J. Glaciol. Geocryol., 30(6), 954-959.

Ding, Y. and J. Liu. 1992. Glacier lake outburst flood disasters in China. Ann. Glaciol., 16, 180-184.

Frey, H., W. Haeberli, A. Linsbauer, C. Huggel and F. Paul. 2010. A multi-level strategy for anticipating future glacier lake formation and associated hazard potentials. Natur. Hazards Earth Syst. Sci. (NHESS), 10(2), 339-352.

Fujita, K., R. Suzuki, T. Nuimura and A. Sakai. 2008. Performance of ASTER and SRTM DEMs, and their potential for assessing glacial lakes in the Lunana region, Bhutan Himalaya. J. Glaciol., 54(185), 220-228.

Fujita, K., A. Sakai, T. Nuimura, S. Yamaguchi and R.R. Sharma. 2009. Recent changes in Imja Glacial Lake and its damming moraine in the Nepal Himalaya revealed by in situ surveys and multi-temporal ASTER imagery. Environ. Res. Lett., 4(4), 045205. (10.1088/1748-9326/4/4/045205.)

Hall, D.K., K.J. Bayr, W. Schöner, R.A. Bindschadler and J.Y.L. Chien. 2003. Consideration of the errors inherent in mapping historical glacier positions in Austria from ground and space (1893-2001). Remote Sens. Environ., 86(4), 566-577.

Huggel, C., A. Kääb, W. Haeberli, P. Teysseire and F. Paul. 2002. Remote sensing based assessment of hazards from glacier lake outbursts: a case study in the Swiss Alps. Can. Geotech. J., 39(2), 316-330.

Kääb, A. and 10 others. 2005. Remote sensing of glacier- and permafrost-related hazards in high mountains: an overview. Natur. Hazards Earth Syst. Sci. (NHESS), 5(4), 527-554.

Komori, J. 2008. Recent expansions of glacial lakes in the Bhutan Himalayas. Quat. Int., 184(1), 177-186.

Li, Z.G. 2010. Glacier and glacial lake variations in Luozha area, Eastern Himalayas, using remote sensing. (PhD thesis, Chinese Academy of Sciences. Institute of Tibetan Plateau Research.)

Liu, J.J., Z.L. Cheng, Y. Li and P.C. Su. 2008. Characteristics of glacier-lake breaks in Tibet. J. Catastroph., 23(1), 55-60. [In Chinese with English summary.]

Liu, S. and 7 others. 2005. Glacier changes since the early 20th century in the Gangrigabu Mountains, Southeast Tibetan Plateau. J. Glaciol. Geocryol., 27(1), 55-63. [In Chinese.]

Mool, P.K., D. Wangda, S.R. Bajracharya, K. Kuzang, D.R. Gurung and S.P. Joshi. 2001a. Inventory of glaciers, glacial lakes and glacial lake outburst floods: monitoring and early warning systems in the Hindu Kush-Himalayan region, Bhutan. Kathmandu, International Centre for Integrated Mountain Development with United Nations Environment Programme/Regional Resource Centre for Asia and the Pacific.

Mool, P.K., S.R. Bajracharya and S.P. Joshi. 2001b. Inventory of glaciers, glacial lakes and glacial lake outburst floods: monitoring and early warning systems in the Hindu Kush-Himalayan region, Nepal. Kathmandu, International Centre for Integrated Mountain Development with United Nations Environment Programme/Regional Resource Centre for Asia and the Pacific.
Narama, C., A. Kääb, M. Duishonakunov and K. Abdrakhmatov. 2010. Spatial variability of recent glacier area changes in the Tien Shan Mountains, Central Asia, using Corona ( 1970), Landsat ( 2000), and ALOS ( 2007) satellite data. Global Planet. Change, 71(1-2), 42-54.

Nayar, A. 2009. When the ice melts. Nature, 461(7267), 1042-1046.

Niederer, P., V. Bilenko, N. Ershova, H. Hurni, S. Yerokhin and D. Maselli. 2008. Tracing glacier wastage in the Northern Tien Shan (Kyrgyzstan/Central Asia) over the last 40 years. Climatic Change, 86(1-2), 227-234.

Paul, F., A. Kääb, M. Maisch, T. Kellenberger and W. Haeberli. 2002. The new remote-sensing-derived Swiss glacier inventory: I. Methods. Ann. Glaciol., 34, 355-361.

Paul, F., A. Kääb, M. Maisch, T. Kellenberger and W. Haeberli. 2004. Rapid disintegration of Alpine glaciers observed with satellite data. Geophys. Res. Lett., 31(21), L21402. (10.1029/ 2004GL020816.)

Quincey, D.J., R.M. Lucas, S.D. Richardson, N.F. Glasser, M.J. Hambrey and J.M. Reynolds. 2005. Optical remote sensing techniques in high-mountain environments: application to glacial hazards. Progr. Phys. Geogr., 29(4), 475-505.

Quincey, D.J. and 6 others. 2007. Early recognition of glacial lake hazards in the Himalaya using remote sensing datasets. Global Planet. Change, 56(1-2), 137-152.

Racoviteanu, A.E., Y. Arnaud, M.W. Williams and J. Ordonez. 2008. Decadal changes in glacier parameters in the Cordillera Blanca, Peru, derived from remote sensing. J. Glaciol., 54(186), 499-510.

Richardson, S.D. and J.M. Reynolds. 2000. An overview of glacial hazards in the Himalayas. Quat. Int., 65/66(1), 31-47.

Sakai, A. and K. Fujita. 2010. Correspondence. Formation conditions of supraglacial lakes on debris-covered glaciers in the Himalaya. J. Glaciol., 56(195), 177-181.

Shrestha, A.B. 2008. Resource manual on flash flood risk management. Module 2: non-structural measures. Kathmandu, International Centre for Integrated Mountain Development.

Wang, X. 2008. Methods and application for the hazard assessment of moraine dammed lake outburst floods in the Himalayas, China. (PhD thesis, Chinese Academy of Science. Cold and Arid Regions Environmental Engineering Research Institute.)

Wang, X. and S.Y. Liu. 2007. An overview of researches on moraine-dammed lake outburst flood hazards. J. Glaciol. Geocryol., 29(4), 626-635. [In Chinese with English summary.]

Wang, X., S.Y. Liu, W.Q. Guo and J.L. Xu. 2008. Assessment and simulation of glacier lake outburst floods for Longbasaba and Pida lakes, China. Mt. Res. Dev., 28(3-4), 310-317.

Wang, Y.T., S.G. Hou and Y.P. Liu. 2009. Glacier changes in the Karlik Shan, eastern Tien Shan, during 1971/72-2001/02. Ann. Glaciol., 50(53), 39-45.

Xin, X.D., T. Yao, Q.H. Ye, L.P. Guo and W. Yang. 2009. Study of the fluctuations of glaciers and lakes around the Ranwu Lake of southeast Tibetan Plateau using remote sensing. J. Glaciol. Geocryol., 31(1), 19-26. [In Chinese with English summary.]

Xu, D. 1988. Characteristics of debris flow caused by outburst of glacial lake in Boqu river, Xizang, China, 1981. Geolournal, 17(4), 569-580.

Yang, W., T. Yao, B. Xu, G. Wu, L. Ma and X. Xin. 2008. Quick ice mass loss and abrupt retreat of the maritime glaciers in the Kangri Karpo Mountains, southeast Tibetan Plateau. Chinese Sci. Bull., 53(16), 2457-2551.

Yang, W., T.D. Yao, B.Q. Xu, L.L. Ma, Z.H. Wang and M. Wan. 2010. Characteristics of recent temperate glacier fluctuations in the Parlung Zangbo River basin, southeast Tibetan Plateau. Chinese Sci. Bull., 55(20), 2097-2102.

Yang, X., B. Xu, W. Yang, D. Qu and P.-N. Lin. 2009. Study of altitudinal lapse rates of $\delta^{18} \mathrm{O}$ in precipitation/river water with seasons on the southeast Tibetan Plateau. Chinese Sci. Bull., 54(16), 2742-2750. 
Yao, T.D. 2010. Glacial fluctuations and its impacts on lakes in the southern Tibetan Plateau. Chinese Sci. Bull., 55(20), 2071.

Yao, T.D., Y.Q. Wang, S.Y. Liu, J.C. Pu, Y.P. Shen and A.X. Lu. 2004. Recent glacial retreat in High Asia in China and its impact on water resource in Northwest China. Sci. China $D, \mathbf{4 7}(12)$, 1065-1075.

Yao, T., J. Pu, A. Lu, Y. Wang and W. Yu. 2007. Recent glacial retreat and its impact on hydrological processes on the Tibetan Plateau, China, and surrounding regions. Arct. Antarct. Alp. Res., 39(4), 642-650.
Yao, T.D., J.W. Ren and B.Q. Xu. 2008. Map of glaciers and lakes on the Tibetan Plateau and adjoining regions. Xi'an, Xi'an Cartographic Publishing House.

Yao, T. and 7 others. 2010. Glacial distribution and mass balance in the Yarlung Zangbo River and its influence on lakes. Chinese Sci. Bull., 55(20), 2072-2078.

Ye, Q., S. Kang, F. Chen and J. Wang. 2006. Monitoring glacier variations on Geladandong mountain, central Tibetan Plateau, from 1969 to 2002 using remote-sensing and GIS technologies. J. Glaciol., 52(179), 537-545. 